\title{
Synthesis of Some New 5-Arylazothiazole Derivatives as Disperse Dyes for Dyeing Polyester Fibers
}

\author{
Mohamed E. Khalifa ${ }^{1,2, *}$, Ehab Abdel-Latif ${ }^{3}$, Fathy A. Amer ${ }^{3}$, Mohamed A. Me twally ${ }^{3}$ \\ ${ }^{1}$ Department of Chemistry, Faculty of Science, Taif Univ ersity, Taif 21974, Kingdom of Saudi Arabia \\ ${ }^{2}$ Higher Institute for Engineering and Technology, New Damietta, Egypt \\ ${ }^{3}$ Department of Chemistry, Faculty of Science, University of Mansoura, Mansoura, Egypt
}

\begin{abstract}
A series of 5-arylazo-2-(arylidenehydrazino)-2-thiazolin-4-one dyes 3 and 4 was prepared by cyclocondensation of hydrazonoyl bromides 2 with various thiosemicarbazone derivatives 1 . While the synthesis of 3-amino-N-(5-arylazo-2-thiazolyl)-thieno[2,3-b]pyrid ine-2-carboxamide dyes 8 was achieved by the reaction of 2-( $N$-chloroacetyl)-5-ary lazo-thiazo le derivatives 5 with 4,6-dimethyl-2-mercaptonicotinonitrile followed by heterocyclization of the obtained sulfide derivatives 7 in a solution of ethanol containing sodium ethoxide. These dyes were applied as disperse dyes for dyeing polyester fibers and their characteristics and fastness properties have been measured. The dyed fibers exhibit very good to excellent washing, perspiration and sublimation fastness properties, with little variation in good to excellent rubbing and light fastness.
\end{abstract}

Keywords Thiosemicarbazone, Thiazolid in-4-one, Mercaptonicotinonitrile, Azo Coupling, Disperse Dyes, Polyester Fibers, Fastness Properties

\section{Introduction}

The chemistry of 2-thiazolines, including new methodologies for their preparation, and recent applications, such as their growing use in organic synthesis in the biological field and asymmetric catalysis as ligands has been recently reviewed[1]. 2-A minothiazoles are known mainly as biologically active compounds with a broad range of activity and as intermediates in the synthesis of antibiotics and dyes[2]. Several papers have been published on the use of these compounds as antimicrobial[3], antifungal[4], anti-inflammatory activity[5], anesthetic[6] and antiviral drugs[7]. 2-A minothiazoles and their derivatives are also used in the syntheses of various types of dyes[8-11]. In continuation of our previous studies[9, 12-15] on the synthesis of a variety of thiazole derivatives fro $m$ the readily obtainable cheapest starting materials for dyeing polyester fabrics, we focused on the synthesis of several new $\mathrm{S} / \mathrm{N}$ heterocyclic azo dyes and their applications as azo-disperse dyes for dyeing polyester fibers. These sulfur and/or nit rogen heterocyclic azo dyes provide strong shades that range from yellow, orange, red, and brown colors.

\section{Results and Discussion}

* Corresponding author:

mohamedezzat200@hotmail.com (Mohamed E. Khalifa)

Published online at http://journal.sapub.org/textile

Copyright (C) 2012 Scientific \& Academic Publishing. All Rights Reserved
Heating of thiosemicarbazones 1 with ethyl arylhydrazonobromoacetates 2 in ethanol containing anhydrous sodium acetate afforded the formation of the corresponding

2-(benzylidenehydrazino)-5-arylazo-thiazolidin-4-one

derivatives 3 and 4 (Scheme 1). The chemical structure of dyes 3 and 4 was based on their elemental analyses and spectral data. The IR spectra of the synthesized dyes 3 and 4 displayed absorption bands corresponding to $\mathrm{NH}$ in the region $3260-3189 \mathrm{~cm}^{-1}$ in addition to the characteristic absorption frequencies in the region 1712-1697 $\mathrm{cm}^{-1}$ corresponding to the carbonyl group. The ${ }^{1} \mathrm{H}$ NMR spectrum of $3 \mathrm{~b}$ revealed a singlet signal at $\delta 2.4$ for the methyl protons (Ar-Me), multiplet in the region $\delta$ 7.1-7.9 for the aromatic and $\mathrm{NH}$ protons, singlet at $\delta 8.5$ for the methine proton $(\mathrm{CH}=\mathrm{N})$, in addition to singlet for the hydrazono proton $(\mathrm{C}=\mathrm{N}-\mathrm{NH})$ at $\delta 11.5 \mathrm{ppm}$.

The 2-( $N$-chloroacetyl)-5-arylazo-thiazole derivatives 5 [15] were reacted with 4,6-dimethyl-2- mercaptonicotinoni trile 6 by refluxing in acetone containing sodium carbonate to yield the corresponding sulfide derivatives 7 , which underwent cyclization on heating in a solution of ethanol containing sodium ethoxide to afford the corresponding thieno-[2,3-b]pyridine derivatives 8 (Scheme 2). The chemical structures of $\mathbf{7}$ and $\mathbf{8}$ were established on the bas is of their elemental analyses and spectral data. The IR spectrum of $7 \mathrm{a}$ is characterized by the presence of strong absorption bands at $3333 \mathrm{~cm}^{-1}$ for the NH stretching, 2221 $\mathrm{cm}^{-1}$ corresponding to the nitrile group and $1699 \mathrm{~cm}^{-1}$ corresponding to the carbonyl group. The IR spectrum of $8 \mathrm{a}$ 
clearly indicated the lack of cyano absorption band and revealed the characteristics of $\mathrm{NH}_{2}$ absorption bands at 3177 , $3280 \mathrm{~cm}^{-1}$ in addition to the carbonyl absorption band at $1632 \mathrm{~cm}^{-1}$. The strong decrease in the carbonyl absorption frequencies is attributed to the highly chelated intra molecular H-bond structure. The ${ }^{1} \mathrm{H}$ NMR spectrum of $7 \mathrm{~b}$ is characterized by the presence of three singlet signals at $\delta 2.4,2.5$ and 2.6 corresponding to three methyl protons, singlet at $\delta 4.2$ for the methylene protons, singlet at $\delta 7.0$ for pyridine $\mathrm{C}_{5}-\mathrm{H}$ proton and multip let at $\delta$ 7.2-7.9 for aro mat ic protons. The ${ }^{1} \mathrm{H}$ NMR spectrum of $8 \mathrm{~b}$ confirmed the lack of the singlet signal that characterized the methylene protons and showed three singlet signals corresponding to the three methyl protons at $\delta 2.4,2.8$ and 3.0, in addition to the singlet signal at $\delta 7.3$ for the pyridine $\mathrm{C}_{5}-\mathrm{H}$ proton and multiplet signal at $\delta$ 7.4-7.9 for the aro matic protons.<smiles>CCOC(=O)N[Al]NN=C(Br)C(=O)OCC</smiles><smiles>O=C1N=C(N/N=C/[Al])S/C1=N\N[Al]</smiles>

3: $\mathrm{Ar}^{\prime}=\mathrm{C}_{6} \mathrm{H}_{5}$ 4: $\mathrm{Ar}^{\prime}=\mathrm{p}-\mathrm{Me}_{2} \mathrm{NC}_{6} \mathrm{H}_{4}$

\begin{tabular}{|c|c|c|c|c|c|}
\hline & $\mathbf{a}$ & $\mathbf{b}$ & c & d & e \\
\hline$r=$ & $\mathrm{C}_{6} \mathrm{H}_{5}$ & $p-\mathrm{MeC}_{6} \mathrm{H}_{4}$ & $p-\mathrm{MeOC}_{6} \mathrm{H}_{4}$ & $p-\mathrm{O}_{2} \mathrm{NC}_{6} \mathrm{H}_{4}$ & $p-\mathrm{BrC}_{6} \mathrm{H}_{4}$ \\
\hline
\end{tabular}

Scheme 1. Synthesis of 2-(benzylidenehydrazino)-5-arylazo-thiazolidin-4-one derivatives 3 and 4<smiles>O=C(CCl)Nc1nc(-c2ccccc2)c(N=N[Al])s1</smiles><smiles>Cc1cc(C)c(C#N)c(S)n1</smiles>

6<smiles>Cc1cc(C)c(C#N)c(SCC(=O)Nc2nc(-c3ccccc3)c(N=N[Al])s2)n1</smiles>

a: $\mathrm{Ar}=\mathrm{C}_{6} \mathrm{H}_{5}$

b: $\mathrm{Ar}=p-\mathrm{MeC}_{6} \mathrm{H}_{4}$

c: $\mathrm{Ar}=p-\mathrm{MeOC}_{6} \mathrm{H}_{4}$

d: $\mathrm{Ar}=p-\mathrm{O}_{2} \mathrm{NC}_{6} \mathrm{H}_{4}$

e: $A r=p-\mathrm{BrC}_{6} \mathrm{H}_{4}$

$\mathrm{K}_{2} \mathrm{CO}_{3}$

Acetone<smiles></smiles><smiles>CCN(CC)CCON</smiles>

8

7

EtOH

NaOEt
Scheme 2. Synthesis of thieno-[2,3-b]pyridine derivatives 8 


\subsection{Abs or ption S pectral Characteristics}

Table 1. Electronic absorption spectra of dyes 3,4 and 8 in dichloromethane

\begin{tabular}{|c|c|c|c|}
\hline \multirow{2}{*}{ Comp. } & \multicolumn{3}{|c|}{ Absorption $\lambda_{\max } \mathrm{nm}$} \\
\cline { 2 - 4 } & $\mathbf{3}$ & $\mathbf{4}$ & $\mathbf{8}$ \\
\hline a & 392 & 390 & 446 \\
\hline b & 394 & 394 & 454 \\
\hline c & 396 & 396 & 456 \\
\hline d & 408 & 452 & 480 \\
\hline e & 406 & 390 & 480 \\
\hline
\end{tabular}

The visible absorption data for the synthesized dyes were measured in dichloromethane and are listed in table (1). The absorption maxima of the synthesized dyes ranged from 390 to $524 \mathrm{~nm}$. Within the series of azo dyes investigated, the relation between the shift observed in the absorption maxima and polar characteristics of substituent, may be summarized as follows:

1. The introduction of an electrondonating group in the para position in the arylhydrazono moiety gives a bathochromic shift relative to the unsubstituted compound.
2. The bathochromic shift accompanying the substituents in the diazo component was in the following order $\mathrm{H} \rightarrow \mathrm{CH}_{3}$ $\rightarrow \mathrm{OCH}_{3} \sim \mathrm{Br} \rightarrow \mathrm{NO}_{2}$

\subsection{Dyeing and Fastness Properties}

The synthesized disperse dyes under investigation were applied to polyester fibers at $2 \%$ shade by high-temperature pressure technique $\left(130^{\circ} \mathrm{C}\right)$ where a range of color shades has been obtained as the visual color shades varied from yellow, golden yellow, orange, reddish brown to brown. Generally, variation in color of these dyes results from the alternation in the diazonium and coupling components. The dyes on polyester fibers were evaluated in terms of their fastness properties using standard method[16] and given in table (2), where fastness to light, sublimation and perspiration was assessed in accordance with AATCC-15 (1985), rubbing fastness test was carried out with a crockmeter (Atlas) in accordance with AATCC-88 (1988) and wash fastness test in accordance with IS: 765-1979.

Table 2. Fastness properties of dyes $\mathbf{3 , 4}$ and 8

\begin{tabular}{|c|c|c|c|c|c|c|c|c|}
\hline \multirow{2}{*}{ Comp. } & \multirow{2}{*}{ Washing } & \multicolumn{2}{|c|}{ Perspiration } & \multicolumn{2}{|c|}{ Rubbing } & \multicolumn{2}{|c|}{ Sublimation fastness } & \multirow{2}{*}{$\begin{array}{l}\text { Light } \\
(40 \mathrm{hr}) \text { ) }\end{array}$} \\
\hline & & Acid & Alkali & Dry & Wet & Alt & $\mathrm{St}$ & \\
\hline $3 a$ & $4-5$ & $4-5$ & $4-5$ & $4-5$ & $4-5$ & 5 & 4 & 5 \\
\hline $3 \mathrm{~b}$ & $4-5$ & $4-5$ & $4-5$ & $3-4$ & 4 & $3-4$ & 2 & $4-5$ \\
\hline $3 \mathrm{c}$ & $4-5$ & $4-5$ & $4-5$ & 4 & $3-4$ & 4 & 4 & 4 \\
\hline $3 \mathrm{~d}$ & 4 & 4 & 4 & $2-3$ & $2-3$ & 4 & 4 & 3 \\
\hline $3 \mathrm{e}$ & $4-5$ & $4-5$ & $4-5$ & 2 & 4 & 4 & $2-3$ & 4 \\
\hline $4 \mathrm{a}$ & $4-5$ & $4-5$ & $4-5$ & $2-3$ & $4-5$ & $4-5$ & 5 & 3 \\
\hline $4 \mathrm{~b}$ & $4-5$ & $4-5$ & $4-5$ & $2-3$ & 4 & 5 & $4-5$ & 3 \\
\hline $4 \mathrm{c}$ & $4-5$ & $4-5$ & $4-5$ & 2 & $2-3$ & $4-5$ & $4-5$ & 3 \\
\hline $4 \mathrm{~d}$ & $4-5$ & $4-5$ & $4-5$ & 3 & 4 & $4-5$ & 4 & 3 \\
\hline $4 \mathrm{e}$ & $4-5$ & $4-5$ & $4-5$ & 4 & $4-5$ & $4-5$ & $2-3$ & 6 \\
\hline $8 \mathrm{a}$ & $4-5$ & $4-5$ & $4-5$ & $3-4$ & 3 & $4-5$ & $4-5$ & 4 \\
\hline $8 \mathrm{~b}$ & $4-5$ & $4-5$ & $4-5$ & 2 & 2 & 3 & 3 & 6 \\
\hline $8 \mathrm{c}$ & $4-5$ & $4-5$ & 4 & 2 & 2 & 4 & 4 & 4 \\
\hline $8 \mathrm{~d}$ & $4-5$ & 4 & $4-5$ & 2 & 2 & 4 & $2-3$ & 4 \\
\hline $8 \mathrm{e}$ & $4-5$ & $4-5$ & $4-5$ & 2 & 2 & $4-5$ & $3-4$ & 3 \\
\hline
\end{tabular}

Alt Alteration; St Staining

Table 3. Optical measurements of dyes $\mathbf{3 , 4}$ and $\mathbf{8}$

\begin{tabular}{|c|c|c|c|c|c|c|c|c|c|}
\hline Dye & $\mathrm{K} / \mathrm{S}$ & $\mathrm{L}^{*}$ & $\mathrm{a}^{*}$ & $\mathrm{~b}^{*}$ & $\mathrm{C}^{*}$ & $\mathrm{~h}$ & $\Delta \mathrm{L}$ & $\Delta \mathrm{c}$ & $\Delta \mathrm{H}$ \\
\hline $3 \mathrm{a}$ & 4.68 & 86.7 & -6.5 & 26.1 & 26.9 & 104 & - & - & - \\
\hline $3 \mathrm{~b}$ & 7.4 & 82.6 & -7.6 & 41.2 & 41.9 & 100 & -4.14 & 15.0 & -3.61 \\
\hline $3 \mathrm{c}$ & 2.59 & 82.3 & 0.3 & 37.7 & 37.7 & 89.6 & -4.4 & 10.7 & -14.5 \\
\hline $3 \mathrm{~d}$ & 0.47 & 87.1 & -7.2 & 29.5 & 30.3 & 103 & 0.38 & 3.41 & -0.37 \\
\hline $3 \mathrm{e}$ & 7.2 & 85.4 & -11 & 47.3 & 48.6 & 103 & -1.36 & 21.7 & -0.61 \\
\hline $4 \mathrm{a}$ & 2.83 & 81.1 & -3.1 & 54.4 & 54.5 & 93.2 & - & - & - \\
\hline $4 \mathrm{~b}$ & 1.62 & 83.1 & -1.5 & 38.5 & 39.0 & 92.2 & 2.01 & -15.5 & -1.03 \\
\hline $4 \mathrm{c}$ & 1.90 & 75.4 & 1.57 & 41.2 & 41.3 & 87.8 & -5.72 & -13.2 & -5.42 \\
\hline $4 \mathrm{~d}$ & 4.25 & 67.5 & 12.1 & 50.6 & 52.0 & 76.5 & -13.6 & -2.45 & -16.7 \\
\hline $4 \mathrm{e}$ & 9.27 & 82.1 & -6.58 & 73.8 & 74.1 & 95.1 & 1.01 & 19.6 & 1.86 \\
\hline $8 \mathrm{a}$ & 0.37 & 82.2 & 2.83 & 29.6 & 29.8 & 84.5 & - & - & - \\
\hline $8 \mathrm{~b}$ & 14.0 & 62.5 & 41.2 & 80.4 & 90.4 & 62.8 & -19.8 & 60.66 & -21.7 \\
\hline $8 \mathrm{c}$ & 7.19 & 63.2 & 25.9 & 68.5 & 73.3 & 69.2 & -19.0 & 43.49 & -15.3 \\
\hline $8 \mathrm{~d}$ & 5.24 & 43.7 & 46.3 & 19.9 & 50.4 & 23.3 & -38.5 & 20.67 & -61.2 \\
\hline $8 \mathrm{e}$ & 9.09 & 61.8 & 35.3 & 70.6 & 79.0 & 63.4 & -20.4 & 49.21 & -21.1 \\
\hline
\end{tabular}




\subsection{Color Ass ess ment}

The color on polyester fibers is expressed in terms of CIELAB values (table 3 ) and the following CIELAB coordinates are measured, lightness $\left(\mathrm{L}^{*}\right)$, chroma $\left(\mathrm{C}^{*}\right)$, hue angle fro $m 0^{\circ}$ to $360^{\circ}(\mathrm{h}),\left(\mathrm{a}^{*}\right)$ value represents the degree of redness (positive) and greenness (negative) and $\left(b^{*}\right)$ represents the degree of yellowness (positive) and blueness (negative). A reflectance spectrophotometer (Gretag Macbeth CE 7000a) was used for the colorimetric measurements on the dyed samples. $\mathrm{K} / \mathrm{S}$ values given by the reflectance spectrometer are calculated at $\lambda_{\max }$ and are directly correlated with the dye concentration on the dye substrate according to the Kubelka-Munk equation: K/S = $(1-\mathrm{R})^{2} / 2 \mathrm{R}$, where $\mathrm{K}=$ absorbance coeffic ient, $\mathrm{S}=$ scattering coefficient, $\mathrm{R}=$ reflectance ratio. The application of the dyes 3, 4 and 8 on polyester fibers has shown that such dyes have good affinity to polyester fibers. As shown in table 3, the color hue of the applied dyes 3 and 4 on polyester fibers is shifted to the greenish direction on the red-green axis as indicated from the negative value of $\mathrm{a}^{*}$, whereas the dyes 3 , 4 and 8 represent degrees of redness to yellowness color hue as indicated from the positive values of $a^{*}$ and $b^{*}$. These results are in line with the previously reported by Müller[17] on the effect of substituent in the dye structure and hue.

\section{Conclusions}

A set of 15 disperse dyes 3, 4 and 8 were synthesized by azo coupling. All of them were investigated for their dyeing characteristics on polyester fibers. The electronic absorption spectra give variable hues fro m yellow to brown on polyester fibers. The dyed fibers exhibit very good to excellent washing, perspiration and sublimation fastness properties with little variation in the good to excellent rubbing fastness. The degree of levelness after washing is indicative of good penetration and the excellent affinity of these dyes for polyester fiber. This in combination with the ease of preparation makes them particularly valuable.

\section{Experimental}

\subsection{Materials and Instrumentation}

Microanalys is of the elements: carbon and hydrogen were determined at Microanalytical Laboratories, Faculty of Science, Mansoura, Cairo and Alexandria Universities. All melting points are in degree centigrade and are uncorrected. Infrared spectra were recorded on a Perkin Elmer 14 spectrometer using potas sium bro mide Waffer technique. ${ }^{1} \mathrm{H}$ NMR spectra were measured on a Bruker WP 300 in $\mathrm{CDCl}_{3}$, DMSO or $\mathrm{CF}_{3} \mathrm{COOD}$ as solvent, using TMS as an internal standard. Mass spectra were recorded on a Finnigan MAT 212 instrument. The substrate used for dyeing (100\% polyester fiber) was kindly provided by Misr Beida Dyers company, Alexandria, Egypt, a product of Misr For
Synthetic Fibers Company, Kafr El-Dawar, Egypt. The colorimetric measurements for the dyed polyester fibers were carried out using a reflectance spectrophotometer (GretagMacbeth CE 7000a). Fastness to washing was carried out using the automatic launder Rotadyer (sponsored by the British Standard Institute - Society of Dyers and Colourists, fastness to perspiration was assessed according to the test sponsored by the (BSS), fastness to rubbing was carried out according to the standard method of testing (BSS) using Crockmeter of Electric Hungarian FD-17 type, fastness to sublimation was carried out using the Electric Japanese Thermotester T-10 type and fastness to light was carried out using the "Weather-o-meter" (Atlas Electric Devices Co. USA), AATCC standard test method.

\subsection{Dyestuff Synthesis}

Synthes is of 2 - (Ben zy lidenehydrazino)-5- arylazothiazo lid in -4-one dyes 3 and 4

A mixture of equimo lar a mounts of thios emicarbazones 1 $(0.005 \mathrm{~mol})$ and ethyl arylhydrazono-bromoacetates $2(0.005$ mol) in ethanol containing anhydrous sodium acetate $(0.5$ gm) was refluxed for $2 \mathrm{~h}$. The products separated on cooling was collected by filtration and washed several times with cold water, dried and recrystallized from ethanol

3a, Yield 62\%; yellow; mp $162-164^{\circ} \mathrm{C}$; IR (KBr) $v=3210$ $(\mathrm{NH}), 1712(\mathrm{CO})$ and $1611(\mathrm{C}=\mathrm{N}) \mathrm{cm}^{-1}$. Anal. calcd. for $\mathrm{C}_{16} \mathrm{H}_{13} \mathrm{~N}_{5} \mathrm{OS}$ (323.37): C, 59.43; H, 4.05; N, 21.66. Found: $\mathrm{C}$, 59.51; H, 4.18; N, 21.77.

3 b, Yield $30 \%$; orange; mp $118-119^{\circ} \mathrm{C}$; IR $(\mathrm{KBr}) v=3227$ $(\mathrm{NH}), 1710(\mathrm{CO})$ and $1638(\mathrm{C}=\mathrm{N}) \mathrm{c} \mathrm{m}^{-1} .{ }^{1} \mathrm{H} \mathrm{NMR}(\mathrm{DMSO})$ : $\delta / \mathrm{ppm}=2.4\left(\mathrm{~s}, 3 \mathrm{H}, \mathrm{CH}_{3}\right), 7.1-7.9(\mathrm{~m}, 10 \mathrm{H}$, Ar- $\mathrm{H}$ and $\mathrm{NH})$, $8.5(\mathrm{~s}, 1 \mathrm{H}, \mathrm{CH}=\mathrm{N}), 11.5(\mathrm{~s}, 1 \mathrm{H}, \mathrm{C}=\mathrm{N}-\mathrm{NH})$. Anal. calcd. for $\mathrm{C}_{17} \mathrm{H}_{15} \mathrm{~N}_{5} \mathrm{OS}$ (337.4): C, 60.52; H, 4.48; N, 20.76. Found: C, 60.71; H, 4.55; N, 20.87.

3c, Yield 77\%; brown; mp $180-183^{\circ} \mathrm{C}$; IR (KBr) $v=3238$ $(\mathrm{NH}), 1699(\mathrm{CO})$ and $1644(\mathrm{C}=\mathrm{N}) \mathrm{c} \mathrm{m}^{-1} .{ }^{1} \mathrm{H}$ NMR (DMSO): $\delta / \mathrm{ppm}=3.8\left(\mathrm{~s}, 3 \mathrm{H}, \mathrm{OCH}_{3}\right), 6.9-7.8(\mathrm{~m}, 10 \mathrm{H}, \mathrm{Ar}-\mathrm{H}$ and $\mathrm{NH})$, $8.3(\mathrm{~s}, 1 \mathrm{H}, \mathrm{CH}=\mathrm{N}), 11.2(\mathrm{~s}, 1 \mathrm{H}, \mathrm{C}=\mathrm{N}-\mathrm{NH})$. Anal. calcd. for $\mathrm{C}_{17} \mathrm{H}_{15} \mathrm{~N}_{5} \mathrm{O}_{2} \mathrm{~S}$ (353.4): C, 57.78; H, 4.28; N, 19.82. Found: $\mathrm{C}$, 57.71; H, 4.32; N, 19.76

$3 \mathrm{~d}$, Yield $68 \%$; yellow; mp $>265^{\circ} \mathrm{C}$; IR $(\mathrm{KBr}) v=3260$ $(\mathrm{NH}), 1708(\mathrm{CO})$ and $1647(\mathrm{C}=\mathrm{N}) \mathrm{cm}^{-1}$. MS $\left(\mathrm{M}^{+} ; \mathrm{EI}\right): \mathrm{m} / \mathrm{z}$ $(\%)=368$ (100). Anal. calcd. for $\mathrm{C}_{16} \mathrm{H}_{12} \mathrm{~N}_{6} \mathrm{O}_{3} \mathrm{~S}$ (368.37): $\mathrm{C}$, 52.17; H, 3.28; N, 22.81. Found: C, 52.24; H, 3.18; N, 22.84.

3e, Yield 20\%; yellow; mp 249-251 ${ }^{\circ}$; IR (KBr) $v=3189$ $(\mathrm{NH}), 1707(\mathrm{CO})$ and $1626(\mathrm{C}=\mathrm{N}) \mathrm{cm}^{-1}$. Anal. calcd. for $\mathrm{C}_{16} \mathrm{H}_{12} \mathrm{BrN}_{5} \mathrm{OS}$ (402.27): C, 47.77; H, 3.01; N, 17.41. Found: C, 47.71; H, 3.08; N, 17.34.

4a, Yield 58\%; yellow; mp 214- $215^{\circ} \mathrm{C}$; IR (KBr) v=3216 $(\mathrm{NH}), 1702(\mathrm{CO})$ and $1623(\mathrm{C}=\mathrm{N}) \mathrm{c} \mathrm{m}^{-1}$. Anal. calcd. for $\mathrm{C}_{18} \mathrm{H}_{18} \mathrm{~N}_{6} \mathrm{OS}$ (366.44): C, 59.00; H, 4.95; N, 22.93. Found: $\mathrm{C}$, $59.11 ; \mathrm{H}, 4.88 ; \mathrm{N}, 23.10$.

4 b, Yield $38 \%$; orange; mp $198-201^{\circ} \mathrm{C}$; IR (KBr) $v=3232$ (NH), $1697(\mathrm{CO})$ and $1634(\mathrm{C}=\mathrm{N}) \mathrm{cm}^{-1} .{ }^{1} \mathrm{H}$ NMR (DMSO): $\delta / \mathrm{ppm}=2.4\left(\mathrm{~s}, 3 \mathrm{H}, \mathrm{CH}_{3}\right), 3.0\left(\mathrm{~s}, 6 \mathrm{H}, 2 \mathrm{CH}_{3}\right), 6.8-7.8(\mathrm{~m}, 9 \mathrm{H}$, Ar-H and $\mathrm{NH}), 8.3(\mathrm{~s}, 1 \mathrm{H}, \mathrm{CH}=\mathrm{N}), 11.1(\mathrm{~s}, 1 \mathrm{H}, \mathrm{C}=\mathrm{N}-\mathrm{NH})$. 
Anal. calcd. for $\mathrm{C}_{19} \mathrm{H}_{20} \mathrm{~N}_{6} \mathrm{OS}$ (380.47): C, 59.98; H, 5.30; N, 22.09. Found: C, 60.09; H, 5.42; N, 22.17.

$4 \mathrm{c}$, Yield $22 \%$; orange; $\mathrm{mp} 197-198^{\circ} \mathrm{C}$; IR $(\mathrm{KBr}) \mathrm{v}=3224$ $(\mathrm{NH}), 1694(\mathrm{CO})$ and $1642(\mathrm{C}=\mathrm{N}) \mathrm{cm}^{-1} .{ }^{1} \mathrm{H}$ NMR (DMSO): $\delta / \mathrm{ppm}=3.0\left(\mathrm{~s}, 6 \mathrm{H}, 2 \mathrm{CH}_{3}\right), 3.8\left(\mathrm{~s}, 3 \mathrm{H}, \mathrm{OCH}_{3}\right), 6.9-7.8(\mathrm{~m}, 9 \mathrm{H}$, Ar-H and $\mathrm{NH}), 8.4(\mathrm{~s}, 1 \mathrm{H}, \mathrm{CH}=\mathrm{N}), 11.2(\mathrm{~s}, 1 \mathrm{H}, \mathrm{C}=\mathrm{N}-\mathrm{NH})$; Anal. calcd. for $\mathrm{C}_{19} \mathrm{H}_{20} \mathrm{~N}_{6} \mathrm{O}_{2} \mathrm{~S}$ (396.47): $\mathrm{C}, 57.56 ; \mathrm{H}, 5.08 ; \mathrm{N}$, 21.20. Found: C, 57.71; H, 5.20; N, 21.36.

4d, Yield 18\%; brown; mp 174- $176^{\circ} \mathrm{C}$; IR $(\mathrm{KBr}) v=3197$ $(\mathrm{NH}), 1709(\mathrm{CO})$ and $1644(\mathrm{C}=\mathrm{N}) \mathrm{cm}^{-1}$. MS $\left(\mathrm{M}^{+} ; \mathrm{EI}\right): \mathrm{m} / \mathrm{z}$ $(\%)=411$ (82). Anal. calcd. for $\mathrm{C}_{18} \mathrm{H}_{17} \mathrm{~N}_{7} \mathrm{O}_{3} \mathrm{~S}(411.44)$ : $\mathrm{C}$, 52.55; H, 4.16; N, 23.83. Found: C, 52.34; H, 4.28; N, 23.94.

$4 \mathrm{e}$, Yield $45 \%$; orange; $\mathrm{mp} 136-138^{\circ} \mathrm{C}$; IR $(\mathrm{KBr}) v=3191$ $(\mathrm{NH}), 1710(\mathrm{CO})$ and $1640(\mathrm{C}=\mathrm{N}) \mathrm{cm}^{-1}$. Anal. calcd. for $\mathrm{C}_{18} \mathrm{H}_{17} \mathrm{BrN}_{6} \mathrm{OS}$ (445.34): C, 48.55; H, 3.85; N, 18.87. Found: C, 47.71; H, 3.78; N, 18.81 .

Synthes is of 2-(3-cyano-4,6-dimethylpyrid in-2-ylth io)-N(5-arylazo-4-phenylthiazol-2-yl)acetamides 7

A mixture of 2-(N-chloroacetyl)-5-arylazo-thiazole derivatives $5(0.01 \mathrm{~mol}), 4$, 6- dimethyl-2-mercaptonicotino nitrile $6(0.01 \mathrm{~mol})$, and anhydrous potassium carbonate $(0.01 \mathrm{~mol})$ in acetone $(30 \mathrm{ml})$ was refluxed for 4 hours. The excess acetone was evaporated under reduced pressure. The residue was washed with water and recrystallized from ethanol.

7a, Yield 25\%; yellow; mp 265-268 $\mathrm{C}$; IR $(\mathrm{KBr}) v=3333$ $(\mathrm{NH}), 2221(\mathrm{CN})$ and $1697(\mathrm{CO}) \mathrm{cm}^{-1} \cdot{ }^{1} \mathrm{H} \quad \mathrm{NMR}$ $\left(\mathrm{CDCl}_{3} / \mathrm{CF}_{3} \mathrm{COOD}\right): \delta / \mathrm{ppm}=2.4\left(\mathrm{~s}, 3 \mathrm{H}, \mathrm{CH}_{3}\right), 2.50(\mathrm{~s}, 3 \mathrm{H}$, $\left.\mathrm{CH}_{3}\right), 4.2\left(\mathrm{~s}, 2 \mathrm{H}, \mathrm{CH}_{2}\right), 6.90$ (s, $1 \mathrm{H}$, pyrid ine $\left.\mathrm{H}-5\right), 7.40-7.90$ (m, $10 \mathrm{H}, \mathrm{Ar}-\mathrm{H}$ ). Anal. calcd. for $\mathrm{C}_{25} \mathrm{H}_{20} \mathrm{~N}_{6} \mathrm{OS}_{2}$ (484.6); C, 61.96; H, 4.16; N, 17.34. Found; C, 62.04; H, 4.19; N, 17.38 .

$7 \mathrm{~b}$, Yield $60 \%$; red; mp 256- $257^{\circ} \mathrm{C}$; IR $(\mathrm{KBr}) \mathrm{v}=3222$ $(\mathrm{NH}), 2222(\mathrm{CN})$ and $1693(\mathrm{CO}) \mathrm{cm}^{-1} .{ }^{1} \mathrm{H}$ NMR $\left(\mathrm{CDCl}_{3} / \mathrm{CF}_{3} \mathrm{COOD}\right): \delta / \mathrm{ppm}=2.4\left(\mathrm{~s}, 3 \mathrm{H}, \mathrm{CH}_{3}\right), 2.5(\mathrm{~s}, 3 \mathrm{H}$, $\left.\mathrm{CH}_{3}\right), 2.6\left(\mathrm{~s}, 3 \mathrm{H}, \mathrm{CH}_{3}\right), 4.2\left(\mathrm{~s}, 2 \mathrm{H}, \mathrm{CH}_{2}\right), 7.0(\mathrm{~s}, 1 \mathrm{H}$, pyridine $\mathrm{H}-5)$, 7.2-7.9 (m, 9H, Ar-H). MS (M $\mathrm{M}^{+}$; EI): $\mathrm{m} / \mathrm{z}(\%)=498$ (18). Anal. calcd. for $\mathrm{C}_{26} \mathrm{H}_{22} \mathrm{~N}_{6} \mathrm{OS}_{2}$ (498.62): $\mathrm{C}, 62.63 ; \mathrm{H}$, 4.45; N, 16.85. Found: C, 62.71; H, 4.40; N, 16.74.

7c, Yield $50 \%$; brown; mp 178- $180^{\circ} \mathrm{C}$; IR $(\mathrm{KBr}) v=3287$ $(\mathrm{NH}), 2219(\mathrm{CN})$ and $1688(\mathrm{CO}) \mathrm{cm}^{-1}$. Anal. calcd. for $\mathrm{C}_{26} \mathrm{H}_{22} \mathrm{~N}_{6} \mathrm{O}_{2} \mathrm{~S}_{2}(514.62)$ : C, 60.68; H, 4.31; N, 16.33. Found: C, 60.63; H, 4.38; N, 16.37 .

$7 \mathrm{~d}$, Yield $72 \%$; brown; $\mathrm{mp}>265^{\circ} \mathrm{C}$; IR $(\mathrm{KBr}) v=3304$ $(\mathrm{NH}), 2228(\mathrm{CN})$ and $1698(\mathrm{CO}) \mathrm{cm}^{-1}$. Anal. calcd. for $\mathrm{C}_{25} \mathrm{H}_{19} \mathrm{~N}_{7} \mathrm{O}_{3} \mathrm{~S}_{2}(529.59)$ : C, 56.70; H, 3.62; N, 18.51. Found: C, 56.71; H, 3.67; N, 18.34 .

7e, Yield $76 \%$; brown; mp 246- $247^{\circ} \mathrm{C}$; IR $(\mathrm{KBr}) v=3311$ $(\mathrm{NH}), 2224(\mathrm{CN})$ and $1696(\mathrm{CO}) \mathrm{cm}^{-1}$. Anal. calcd. for $\mathrm{C}_{25} \mathrm{H}_{19} \mathrm{BrN}_{6} \mathrm{OS}_{2}$ (563.49): C, 53.29; H, 3.40; N, 14.91. Found: C, 53.21; H, 3.33; N, 14.94 .

Synthesis of 3-a mino-N-(4-phenyl-5-arylazo-2-thiazoly l) -thieno[2,3-b]pyridine-2-carbo xamide dyes 8

The nicotinonitrile derivative $7(0.005 \mathrm{~mol})$ was added to a solution of sodium ethoxide (fro 0.005 mol sodium metal) in absolute ethanol $(30 \mathrm{ml})$. The solution was refluxed for 2 hours, left to cool, and diluted with cooled water $(50 \mathrm{ml})$. The solid obtained was filtered and recrystallized from ethanol. 8a, Yield $43 \%$; red; $\mathrm{mp}>265^{\circ} \mathrm{C}$; $\mathrm{IR}(\mathrm{KBr}) \mathrm{v}=3177,3280$ $\left(\mathrm{NH}, \quad \mathrm{NH}_{2}\right)$ and $1632 \quad(\mathrm{CO}) \mathrm{cm}^{-1} .{ }^{1} \mathrm{H} \quad \mathrm{NMR}$ $\left(\mathrm{CDCl}_{3} / \mathrm{CF}_{3} \mathrm{COOD}\right): \delta / \mathrm{ppm}=2.4\left(\mathrm{~s}, 3 \mathrm{H}, \mathrm{CH}_{3}\right), 2.5(\mathrm{~s}, 3 \mathrm{H}$, $\left.\mathrm{CH}_{3}\right), 7.0$ (s, 1H, pyrid ine H-5), 7.3-7.8 (m, 10H, Ar-H). Anal. calcd. for $\mathrm{C}_{25} \mathrm{H}_{20} \mathrm{~N}_{6} \mathrm{OS}_{2}$ (484.6): $\mathrm{C}, 61.96 ; \mathrm{H}, 4.16 ; \mathrm{N}$, 17.34. Found: C, 62.08; H, 4.22; N, 17.27.

8b, Yield 50\%; red; $\mathrm{mp}>265^{\circ} \mathrm{C}$; IR $(\mathrm{KBr}) \mathrm{v}=3494,3329$, $3189\left(\mathrm{NH}, \mathrm{NH}_{2}\right)$ and $1636(\mathrm{CO}) \mathrm{cm}^{-1} \cdot{ }^{1} \mathrm{H} \quad \mathrm{NMR}$ $\left(\mathrm{CDCl}_{3} / \mathrm{CF}_{3} \mathrm{COOD}\right): \delta / \mathrm{ppm}=2.4\left(\mathrm{~s}, 3 \mathrm{H}, \mathrm{CH}_{3}\right), 2.8(\mathrm{~s}, 3 \mathrm{H}$, $\left.\mathrm{CH}_{3}\right), 3.0\left(\mathrm{~s}, 3 \mathrm{H}, \mathrm{CH}_{3}\right), 7.3(\mathrm{~s}, 1 \mathrm{H}$, pyridine $\mathrm{H}-5), 7.4-7.9(\mathrm{~m}$, $9 \mathrm{H}, \mathrm{Ar}-\mathrm{H})$. MS $\left(\mathrm{M}^{+} ; \mathrm{EI}\right): \mathrm{m} / \mathrm{z}(\%)=498$ (23). Anal. calcd. for $\mathrm{C}_{26} \mathrm{H}_{22} \mathrm{~N}_{6} \mathrm{OS}_{2}$ (498.62): $\mathrm{C}, 62.63 ; \mathrm{H}, 4.45 ; \mathrm{N}, 16.85$. Found: C, 62.68; H, 4.52; N, 16.76 .

8c, Yield 64\%; brown; mp 264- $266^{\circ} \mathrm{C}$; IR $(\mathrm{KBr}) \mathrm{v}=3438$, $3315\left(\mathrm{NH}, \mathrm{NH}_{2}\right)$ and $1636(\mathrm{CO}) \mathrm{cm}^{-1}$. Anal. calcd. for $\mathrm{C}_{26} \mathrm{H}_{22} \mathrm{~N}_{6} \mathrm{O}_{2} \mathrm{~S}_{2}$ (514.62): $\mathrm{C}, 60.68 ; \mathrm{H}, 4.31 ; \mathrm{N}, 16.33$. Found: C, 60.60; H, 4.40; N, 16.26 .

8d, Yield 65\%; brown; $m p>265^{\circ} \mathrm{C}$; IR $(\mathrm{KBr}) \mathrm{v}=3418$, $3293\left(\mathrm{NH}, \mathrm{NH}_{2}\right)$ and $1644(\mathrm{CO}) \mathrm{cm}^{-1}$. Anal. calcd. for $\mathrm{C}_{25} \mathrm{H}_{19} \mathrm{~N}_{7} \mathrm{O}_{3} \mathrm{~S}_{2}$ (529.59): C, 56.70; H, 3.62; N, 18.51. Found: C, $56.72 ; \mathrm{H}, 3.68 ; \mathrm{N}, 18.42$.

8e, Yield 48\%; brown; mp 254- $255^{\circ} \mathrm{C}$; IR (KBr) $v=3444$, $3357,3289\left(\mathrm{NH}, \mathrm{NH}_{2}\right)$ and $1638(\mathrm{CO}) \mathrm{cm}^{-1}$. Anal. calcd. for $\mathrm{C}_{25} \mathrm{H}_{19} \mathrm{BrN}_{6} \mathrm{OS}_{2}$ (563.49): $\mathrm{C}, 53.29 ; \mathrm{H}, 3.40 ; \mathrm{N}, 14.91$. Found: C, 53.41; H, 3.45; N, 14.97 .

\subsection{Dyeing of Polyester Fibers and Dyeing Properties}

\subsubsection{Preparation of Dye Dispersion}

Dispersion of the dye was produced by dissolving the appropriate a mount of dye ( $0.1 \mathrm{~g}$ dye/ $5 \mathrm{~g}$ fiber, $2 \%$ shade $)$ in $1 \mathrm{ml}$ acetone and then added dropwise with stirring to a solution of Setamol WS $(0.5-1.5)$, an anionic dispersing agent of BASF (sodium salt of a condensation product of naphthalene sulfonic acid and formaldehyde). The dyestuff dispersion was added to the dyebath at $60^{\circ} \mathrm{C}$ through a fine mesh sieve or filter cloth.

\subsubsection{Dyeing Procedure}

The dye bath was prepared with liquor ratio 20:1 using sealed stainless steel dye pots of $250 \mathrm{ml}$ capacity in "Galvanin-Marino VI-Italy" dyeing machine. Additional dispersing agent (0.5-1.0 g/l Setamol WS of BASF) was added and the $\mathrm{pH}$ of the bath adjusted to 5.5 using glacial acetic acid. The polyester fibers was immersed and dyeing carried out by raising the dye bath temperature from 20 to $130^{\circ} \mathrm{C}$ at a rate of $3^{\circ} \mathrm{C} / \mathrm{min}$ and holding at this temperature for $60 \mathrm{~min}$ before rapidly cooling to $50^{\circ} \mathrm{C}$ at $9.9^{\circ} \mathrm{C} / \mathrm{min}$. The dyed fibers was then rinsed with cold water, reduction-cleared using $2 \mathrm{cc} / 1$ caustic soda solution $32.5 \%$ $\left(71^{\circ} \mathrm{Tw}\right), 2 \mathrm{~g} / 1$ sodium hydrosulphite and $0.5 \mathrm{~g} / 1$ Hostapal CV conc. non-ionic wetting agent of Clariant at $75-85^{\circ} \mathrm{C}$ for 15-30 minutes and soaped with $2 \%$ nonionic detergent and ammonia $(\mathrm{pH} 8.5)$ at $50^{\circ} \mathrm{C}$ for 30 minutes to improve washing fastness then drying in a pre-drier without contact, up to a residual moisture of appro ximately $30 \%$ followed by final drying which be carried out on a hot flue. 


\subsubsection{Fastness Properties}

(i) Fastness to washing. A specimen of dyed polyester sample was stitched between two pieces of undyed cotton and polyester fabrics $(10 \mathrm{~cm} \times 4 \mathrm{~cm})$, all approximately of equal weight and then washed at $50^{\circ} \mathrm{C}$.

(ii) Fastness to acid and alkaline perspiration. The AATCC standard test method 15-1960 was used. The acid solution $(\mathrm{pH}=3.5)$ contained sodium chloride $(10 \mathrm{~g} / 1)$, lact ic acid U.S.P $85 \%$ ( $1 \mathrm{~g} / \mathrm{l})$, disodium orthophosphate anhydrous ( $1 \mathrm{~g} / \mathrm{l})$ and histidine monohydrochloride $(0.25 \mathrm{~g} / 1)$. The alkaline solution contained sodium chloride $(10 \mathrm{~g} / \mathrm{l})$, ammonium carbonate (4 g/l), disodium orthophosphate anhydrous $(1 \mathrm{~g} / \mathrm{l})$ and histidine monohydrochloride $(0.25$ $\mathrm{g} / \mathrm{l})$.

A composite specimen was made from the dyed sample as a layer between undyed cotton and polyester fabrics as the same weight as the dyed sample, composite specimen was immersed in the perspiration solution for 30 minutes with occasional agitation and squeezing to insure complete wetting, then stitched between the plastic in such a way that the dyed sample will be in a vertical position when placed in the oven. The loaded sample was kept in an oven at $37^{\circ} \mathrm{C}$ for $6-8$ hours and then dried by conventional means.

(iii) Fastness to rubbing. The dyed polyester fiber was placed on the base of crockmeter, so that it rested flat on the abrasive cloth with its long dimension in the direction of rubbing. A square of white testing cloth was mount over the end of the finger which protects downward on the dry specimen sliding back and forth twenty times by making ten complete turns of the crank at the rate of one turn per second. For wet rubbing test, the testing squares were thoroughly wet in distilled water and squeezed between filter papers through hand wringer under standard conditions. The rest of the procedure is the same as the dry crocking test.

(iv) Fastness to sublimation. The fastness to sublimation was ass essed according to ISO/R 10S/IV - Part 2. The dyed polyester fiber was stitched between two pieces of white polyester and cotton fabrics, all of equal length. The samples were treated at $185{ }^{\circ} \mathrm{C}$ and $210{ }^{\circ} \mathrm{C}$ for 30 seconds, then conditioning for 16 hours.

(v) Fastness to light. The tested samples and standard blue scales were exposed to the "Weather-o-meter" (Atlas Electric Devices Co. USA). The exposure of both was discontinued at one of the time indicated in AATCC standard of $5,10,20,40,80,160,320$ and 640 hours, at which it shows just appreciable fading. In the present work the dyed fabrics were exposed to light for 40 hours, after which the fibers were allowed to lie in the dark at room temperature for about two hours in order to cool-off and regain normal mo isture from air.

\section{REFERENCES}

[1] A.-C. Gaumont, M. Gulea and J. Levillain, " An Overview of the Chemistry of 2-Thiazolines", Chem. Rev., vol. 109, no.3, pp. 1371-1401, 2009

[2] U.G. Ibatullin, T.F. Petrushina, L.Y. Leitis, I.Z. Minibaev and B.O. Logvin, Khim. Geterotsitl. Soedin., pp. 715, 1993

[3] P.C. Hang and J.F. Honek, " Electronic structure calculations on the thiazole-containing antibiotic thiostrepton: molecular mechanics, semi-empirical and ab initio analyses", Bioorg. Med. Chem. Lett., vol.15, no. 5, pp. 1471- 1474, 2005

[4] P. Beuchet, M. Varache-Lembège, A. Neveu, J.-M. Léger, J. Vercauteren, S. Larrouture, G. Deffieux, A. Nuhrich, " New 2-sulfonamidothiazoles substituted at C-4: synthesis of poly oxygenated aryl derivatives and in vitro evaluation of antifungal activity", Eur. J. Med. Chem., vol. 34, no. 9, pp. 773- 779, 1999

[5] A. Geronikaki, P. Vicini, N. Dabarakis, A. Lagunin, V. Poroikov, J. Dearden, H. Modarresi, M. Hewitt and G. Theophilidis, "Evaluation of the local anaesthetic activity of 3 -aminobenzo[d]isothiazole derivatives using the rat sciatic nerve model", Eur. J. Med. Chem., vol. 44, no. 2, pp. 473-481, 2009

[6] C. Papadopoulou, A. Geronikaki and D. Hadjipavlou-Litina, "Synthesis and biological evaluation of new thiazolyl/ benzothiazolyl-amides, derivatives of4-phenyl-piperazine ", II Farmaco, vol. 60, no. 11-12, pp. 969- 973, 2005

[7] A. Kreutzberger and H. Schimmelpfennig, "[Antiviral drugs, XVIII: 2-Aminothiazoles by cleavage of the S-S-bond of disulfidodicarbamidine", Arch. Pharm., vol. 314, no.5, pp. 385- 391, 1981

[8] D. Keil, R. Flaig, A. Schroeder and H. Hartmann, Dyes and Pigments, "Synthesis and characterisation of methine dyes derived from $N, N$-disubstituted 2-aminoselenazoles and some of their heterocyclic sulfur analogues", vol. 50, no. 1, pp. 6776,2001

[9] M.A. Metwally, E. Abdel-latif, A.M. Khalil, F.A. Amer and G. Kaupp, Dyes and Pigments, "New azodisperse dyes with thiazole ring for dy eing poly ester fabrics", vol. 62, no. 2, pp. 181- 195, 2004

[10] K. Singh, S. Singh and J.A. Tay lor, " Monoazo disperse dy es - part 1: synthesis, spectroscopic studies and technical evaluation of monoazo disperse dyesderived from 2-aminothiazoles", Dyes and Pigments, vol. 54, no. 3, pp. 189- 200, 2002

[11] M.S. Yen and I.J. Wang, "Synthesis and solvent characteristics of bishetaryl monoazodyes derived from polysubstituted-2-aminothiophene derivatives", Dyes and Pigments, vol. 67, no. 3, pp. 183-188, 2005

[12] Metwally M. A., Abdel-Latif E. and Amer F. A., "New 4-ary lazo-2- (substituted)-3- phenyl-1,3- thiazolidin-5-ones as disperse dy es part 1", J. Text. Assoc., Nov.- Dec., pp. $155-$ 159,2001

[13] Metwally M. A., Abdel-Latif E. and Amer F. A., "New 4-arylazo-2- (substituted)-3- phenyl-1,3- thiazolidin-5-ones as disperse dy es part 2", J. Text. Assoc., Nov.- Dec., 149- 154, 2002

[14] Metwally M. A., Etman H. A., Gafer H. E. and Khalil A. M., " New disperse dyes derived 1,3- thiazolidin-4- ones and 5ones for dy eing polester fabrics ", Advances in Color Science and Technology, vol. 7, no. 3, pp. 71-78, 2004 
[15] Metwally M. A., Abdel-Latif E., Amer F. A. and Kaupp G., "Synthesis of new 5-thiazoyl azo-disperse dyes for dyeing poly ester fabrics", Dy es and Pigments, vol. 60, no. 3, pp. 249264, 2004

[16] Standard methods for the determination of the color fastness of textiles and leather, 5th Edn[Bradford: SDC], 1990
[17] Müller C, "Recent developments in the chemistry of disperse dyes and their intermediate", American Dyestuff Reporter, vol. 59 , no. 5 , pp. $37-44,1970$ 